\title{
Assisting Farmers to Produce High-quality Medicinal Herbs
}

\author{
Jeanine M. Davis ${ }^{1}$ \\ Department of Horticultural Science, North Carolina State University, Mountain Horticultural Crops \\ Research and Extension Center, 455 Research Drive, Mills River, NC 28759
}

Additional index words. Actaea racemosa, Allium tricoccum, botanical, Echinacea purpurea,

Hydrastis canadensis, Sanguinaria canadensis

\begin{abstract}
Farmers are looking for new crops to grow to diversify their farms and increase profitability. Medicinal herbs are often of interest because they are generally perceived as being easy to grow, in high demand, return good prices, and serve as useful rotational crops. In reality, most farmers who have not previously grown medicinal herbs do not understand the global herb market. They do not know how to find a buyer or which herbs to grow. To help growers produce and market medicinal herbs, we initiated the Medicinal Herbs for Commerce Project. We also conducted studies on production problems for a variety of herbs. An issue that should be addressed is that there are hundreds of medicinal herbs in commerce and it is impossible for a small number of research programs to independently answer all the questions that are being asked by the industry. Developing a consortium of researchers around the world to coordinate efforts on how best to grow and process medicinal herbs and to create a database of information for farmers and agricultural advisors would be a great service for this industry.
\end{abstract}

U.S. farmers are looking for new crops that will help diversify their farms and increase their profits. With the rising popularity of natural products, some farmers are interested in growing medicinal herbs. The dietary supplement industry is growing with global sales estimated at $\$ 84.5$ billion for $2010(\mathrm{Nu}-$ trition Business Journal, 2011). The strong "buy local" movement in the United States and new federal regulations affecting the manufacturers (U.S. Food and Drug Administration, 2012) favor increased domestic production of raw materials for the medicinal herb industry. Still, few farmers in the United States are growing medicinal herbs because they do not know which herbs to grow, how to produce and process them, or how to access the markets. Our interactions with farmers in North Carolina also revealed that they are not aware of the good agricultural practices (American Herbal Products Association, 2006) required by most buyers or the federally

Received for publication 1 Feb. 2012. Accepted for publication 4 May 2012.

This paper was part of the colloquium "Research Highlights and Commercial Application of Medicinal Plants" held 27 Sept. 2011 at the ASHS Conference, Waikoloa, HI, and sponsored by the Working Group of Asian Horticulture (WGAH) and the Association of Horticulturists of Indian Origin (AHIO).

I thank all the funding agencies that made the research and extension projects mentioned in this article possible. That includes the Alcoa Corporation, GoldenLeaf Foundation, Nature's Way, North Carolina Department of Agriculture and Consumer Services, North Carolina Rural Economic Development Center, North Carolina Tobacco Trust Fund Commission, University of North Carolina Research Competitiveness Fund, and Wilcox Natural Products. I also thank all the research technicians, graduate students, faculty, growers, and herb buyers who worked on these projects with a special thanks to George Cox, Greg Cumberford, David Danehower, Jackie Greenfield, Agatha Grimsley, David Grimsley, Amy Hamilton, Vicky Heatherly, Libby Hinsley, Joe-Ann McCoy, Maria Onofrietti, Dawn Reardon, and Stephen "Woody" Woodward.

${ }^{1}$ To whom reprint requests should be addressed; e-mail Jeanine_Davis@ncsu.edu. mandated current good manufacturing practices, which affect raw material purchasing by manufacturers (U.S. Food Drug and Administration, 2012).

North Carolina has been an important source for wild-harvested roots and herbs for hundreds of years (Persons and Davis, 2007). For the past 25 years or so, some farmers in North Carolina have cultivated medicinal herbs in their woods and open fields. Because agricultural production was not keeping pace with the growth of the rest of industry, we surveyed former and current medicinal herb farmers in the state to ask about their experiences. Through these surveys we learned there were many issues related to cultivation and marketing of these herbs that restricted expansion of agricultural production in the state.

\section{MEDICINAL HERBS FOR COMMERCE PROJECT}

In 2004, we initiated a 4-year project designed to help North Carolina farmers produce medicinal herbs in the quality and quantity necessary to be competitive on the global market. This "Medicinal Herbs for Commerce Project" was funded by grants from the Golden Leaf Foundation, the North Carolina Tobacco Trust Fund Commission, the North Carolina Department of Agriculture and Consumer Services, and the Rural Center through the Land of Sky Regional Council. We advertised across the state for farmers willing to participate in the project and received over 130 applications. To meet the selection criteria, farmers had to have commercial farming experience and immediate access to tractors, transplanters, irrigation, and dryers. Over the course of the project, almost 50 farmers from across the state were involved. During the first 2 years, farmers were given $\$ 5000$ grants to produce 1 or 2 acres of herbs (Fig. 1). Seven buyers worked with the project to help select the herbs to be grown, assess the quality of the herbs produced, buy the herbs, and build relationships with the farmers. Over the 4 years, the farmers learned how to grow, propagate, harvest, clean, dry, and market a wide variety of medicinal herbs. The herbs produced ranged from those requiring full sun including purple coneflower [Echinacea purpurea (L.) Moench], valerian (Valeriana officinalis L.), skullcap (Scutellaria lateriflora L.), and California poppy (Eschscholzia californica Cham.) to shade-requiring forest herbs including ginseng (Panex quinquifolius L.), goldenseal (Hydrastis canadensis L.), bloodroot (Sanguinaria canadensis L.), and black cohosh (Actaea racemosa L.). We also conducted annual training sessions for extension agents so they could assist farmers in their counties, wrote production leaflets on a variety of herbs and related topics, designed and built herb dryers, prepared enterprise budgets, and spoke about the project and its outcomes at grower conferences around the state. Information about this project can be accessed at $<$ http://ncspecialtycrops.org/medherbs $>$.

\section{RESEARCH}

We have conducted many research studies over the past 24 years to resolve production problems that medicinal herb growers encountered. Here are examples of research projects on five of the plants we studied.

Goldenseal. One of our earliest projects was on goldenseal (Persons and Davis, 2007), a plant native to much of North America. It grows naturally in moist, rich hardwood forests. It is a low-growing, herbaceous perennial valued for its bright yellow thickened rhizomes and fibrous roots (hereafter referred to as "roots"), which are rich in alkaloids, most notably, berberine. It has many traditional uses, especially for treatment of mouth sores, eye and ear infections, and as a topical antiseptic. It is now used to treat many conditions including infection, inflammation, cancer, and HIV. Although goldenseal is native to the hardwood forests of western North Carolina, many wild populations are not vigorous, and growers raising it in forest gardens reported that the plants grew slowly. This was in sharp contrast to forest production sites I visited in Tennessee and Kentucky. The environments in those areas did not seem very different from 


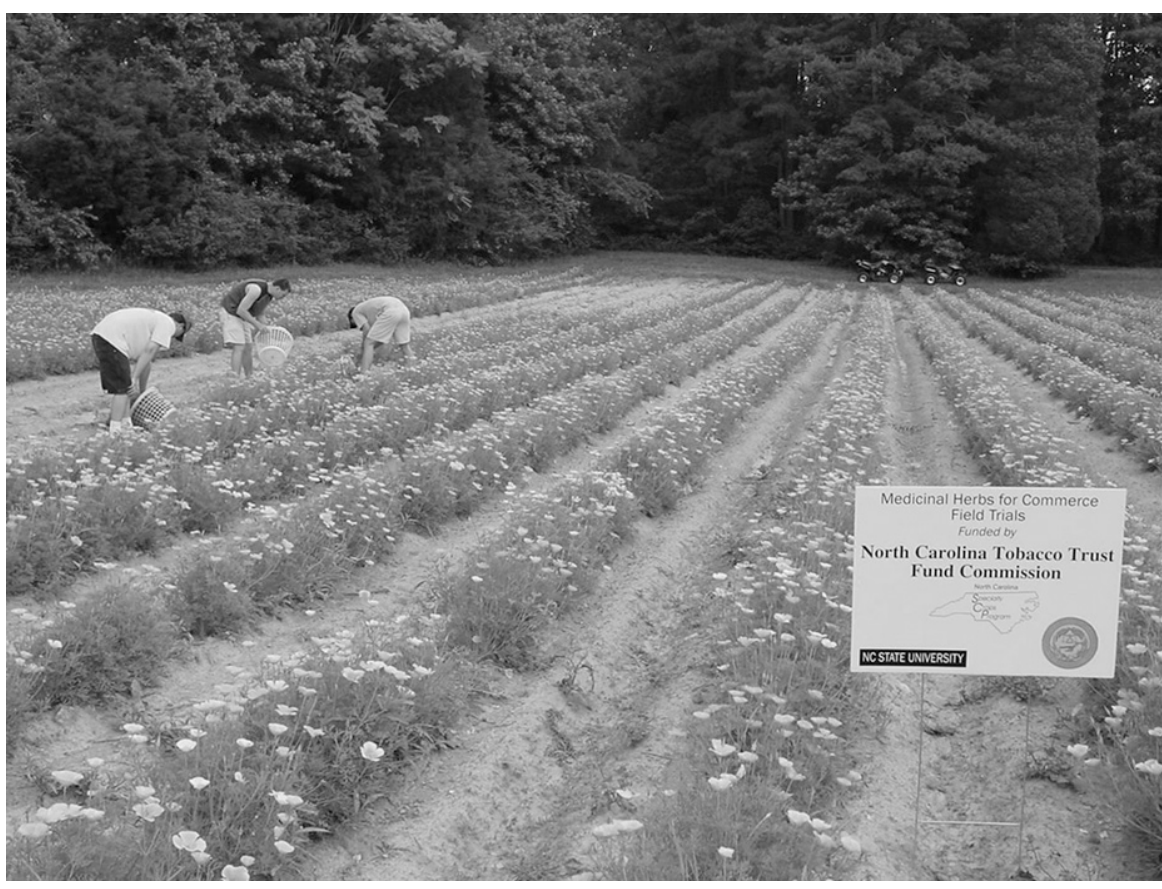

Fig. 1. Field of California poppy grown for the Medicinal Herbs for Commerce Project.

that in western North Carolina, so we chose to look at some soil factors. Soils in western North Carolina hardwood forests are often acidic and low in available phosphorus. Konsler and Shelton (1990) found that ginseng roots grown in western North Carolina forest soil could be improved by increasing soil $\mathrm{pH}$ and phosphorus (P) levels. In the early 1990s we studied the effects of lime, nitrogen $(\mathrm{N})$, and phosphorus on goldenseal growth, root yield, and alkaloid content (Persons and Davis, 2007). The 3-year study was conducted on individual goldenseal plants grown in four 1-L pots of local forest topsoil. The study was a factorial arrangement of dolomitic lime at $0.2,2.0,3.8$, and $5.7 \mathrm{~kg} \cdot \mathrm{m}^{-3}$; superphosphate at $0,0.1,0.2,0.3 \mathrm{~kg} \cdot \mathrm{m}^{-3} \mathrm{P}$; and calcium nitrate at $0,0.1,0.2,0.3 \mathrm{~kg} \cdot \mathrm{m}^{-3} \mathrm{~N}$ in a randomized complete block design with eight replications. One of the most important findings from that study was that goldenseal root growth responded favorably to the addition of lime increasing soil $\mathrm{pH}$ from 4.95 to 6.02 (Fig. 2). In contrast, the total root alkaloid content was highest at $\mathrm{pH} 4.95$ (9.2\% of dry weight) and decreased with increasing lime $(6.5 \%$ of dry weight at $\mathrm{pH} 6.02$ ). With all things considered, soil limed to a $\mathrm{pH}$ of $\approx 5.8$ resulted in the best combination of root and alkaloid yield per unit land area.

While our goldenseal study was being conducted, a study in New York revealed that ginseng benefited from additional calcium applied in the form of gypsum (Beyfuss, 2000). Because our goldenseal study used dolomitic lime to adjust soil $\mathrm{pH}$, we could not distinguish between effects caused by changes in soil $\mathrm{pH}$ or calcium. Thus, we initiated a 3-year study on established beds of goldenseal with a soil pH of 6.5 (Persons and Davis, 2007). Treatments were 0,2802 , and $5605 \mathrm{~kg} \cdot \mathrm{ha}^{-1}$ of calcium applied in the form of gypsum with four replications. In contrast to ginseng, goldenseal root yields decreased and foliar disease symptoms increased with increasing soil calcium (data not shown). Goldenseal alkaloid concentration, however, did not respond to calcium (data not shown). These results, along with others on propagation and shade level, helped growers establish healthy populations of cultivated goldenseal, and now there are goldenseal growers scattered throughout the southern Appalachian Mountains.

Bloodroot. Bloodroot is another lowgrowing, native, herbaceous perennial found in forests throughout North America (Persons and Davis, 2007). It is one of the first plants to bloom in the spring and is often cultivated as an ornamental. As a medicinal, it is valued for its rhizome, which is used for many purposes, including treatment of skin lesions and skin cancer. The rhizome is also a source of a red dye used in natural craft projects such as basketry. In 2002, a German company wanted farmers in our region to produce large quantities of bloodroot, but it was taking too long for the plant to reach maturity and farmers were having difficulty propagating it efficiently. This became the research topic for a graduate student project (Onofrietti, 2007). Propagation studies were conducted under an artificial shade structure and in a mixed hardwood forest. Bloodroot rhizomes were cut and sorted into three propagule treatments, rhizome sections with a bud, rhizome sections without a visible bud, and whole rhizome pieces, with four replications. In both settings, rhizome pieces with buds and whole rhizome pieces showed much higher emergence $(94 \%$ and $96 \%$ under artificial shade and $89 \%$ and $86 \%$ in the woods, respectively) in the first year compared with pieces that did not contain buds. By the second year there was no difference among treatments in emergence or

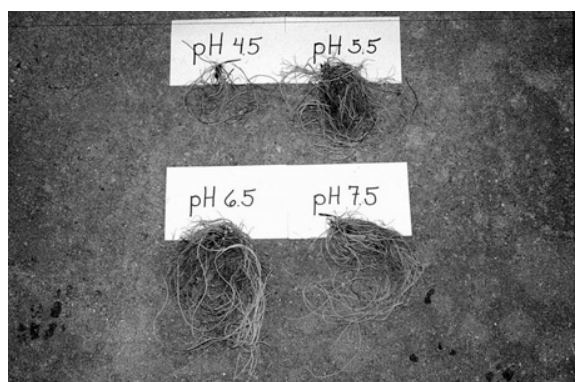

Fig. 2. Response of goldenseal root and rhizome growth to lime and soil $\mathrm{pH}$. The $\mathrm{pH}$ values indicated in the photograph were the target $\mathrm{pH}$ values at the beginning of the study (the initial $\mathrm{pH}$ of the unamended forest soil was 4.4 and was adjusted to the target $\mathrm{pH}$ values with dolomitic lime). The average $\mathrm{pH}$ values of the growing media at the end of the 3-year growth period, from lowest to highest were $4.95,5.60,6.02$, and 6.44 .

final root yield. The final rhizome yields after 2 years of growth, however, were much greater in the artificial shade plots than the woods plots $\left(95.4 \mathrm{~g}\right.$ dry weight $/ \mathrm{m}^{2}$ and $4.5 \mathrm{~g}$ dry weight $/ \mathrm{m}^{2}$, respectively) but the sanguinarine content was higher for woods grown material ( $3.2 \%$ of dry weight) than that grown under the artificial shade ( $2.2 \%$ of dry weight). We have observed these big yield differences between medicinal herbs grown in the woods or under artificial shade many times before. They are usually attributed to differences in soil $\mathrm{pH}$ and fertility; competition with other plants and trees for water, nutrients, and light; and damage caused by animal browse. Even with the higher yields obtained under artificial shade, it still takes bloodroot 5 to 7 years to reach a harvestable size and current wholesale prices for the raw material ( $\$ 11$ to $\$ 13$ per dried kilogram) usually do not cover costs of production. Rising interest in bloodroot as a dye plant, however, may make production more cost-effective.

Black cohosh. Another graduate student conducted her Ph.D. research on black cohosh (McCoy, 2004), a tall, shrub-like plant that grows in rich, moist, open forest coves throughout most of eastern North America. It is an herbaceous perennial with a thickened, knobby rhizome. The rhizome is best known for its use in preparations to treat unpleasant menopausal symptoms. For her propagation studies, she divided rhizomes into four treatments, an intact rhizome with roots, a 10- to $30-\mathrm{g}$ piece taken from the terminal end of a rhizome (has a big terminal bud), a 10 - to $20-\mathrm{g}$ piece with one or two buds from the midsection of a rhizome, and a 20- to 30-g piece with two to four buds from the midsection of a rhizome. The study was conducted in a forest, on the forest edge, and under an artificial shade structure with four treatment replications at each site (McCoy et al., 2007). After 3 years of growth, the black cohosh propagules planted in the woods increased in weight $\approx 0.85$-fold, those on the forest edge increased 1.6-fold, and those grown under artificial shade increased $\approx 9.1$-fold. Yields 
were greatest from whole rhizomes and terminal bud pieces. At the time these studies were being conducted, the prices being paid for dried rhizomes $(\$ 11 /$ dried $\mathrm{kg}$ ) were well below the costs of production. A recent upsurge in demand for organically grown black cohosh, however, has increased prices to where a grower could make a profit if yields were good.

Ramps. Several field studies were conducted on ramps (Allium tricoccum Aiton), a popular native plant used as a food and spring tonic (Persons and Davis, 2007). Ramps, also known as wild leeks, grow in the forests of much of eastern North America, emerging in early spring and dying back by midsummer. The bulb and young leaves are harvested in early spring. In 2001 we initiated a study to examine the influence of soil $\mathrm{pH}$ and soil calcium levels on establishment and yields of ramp bulbs planted in the fall and the spring (Persons and Davis, 2007). The native soil $\mathrm{pH}$ was 4.9 and the targeted $\mathrm{pH}$ levels were $4.9,5.5,6.0$, and 6.5 . The calcium treatments were $0,1121,3363$, and 5605 $\mathrm{kg} \cdot \mathrm{ha}^{-1}$ calcium. Materials used to create the $\mathrm{pH}$ and calcium treatments, and keep magnesium balanced between calcium treatments, were gypsum, magnesium oxide, and olivine $\left(\mathrm{MgSiO}_{3}\right)$. Annual spring plant stands decreased with increasing soil $\mathrm{pH}$ but rose with increasing soil calcium (data not shown). For example, in late April of the first season of growth, plant stands were $77 \%, 74 \%, 70 \%$, and $66 \%$ for the target soil $\mathrm{pH}$ levels of 4.9 , $5.5,6.0$, and 6.5 , respectively, and $63 \%, 70 \%$, $75 \%$, and $78 \%$ for the calcium $(\mathrm{Ca})$ treatments of $0,1121,3363$, and $5605 \mathrm{~kg} \cdot \mathrm{ha}^{-1} \mathrm{Ca}$, respectively. Fall planting provided a better plant stand than spring plantings (data not shown). For example, in the second season of growth the fall planting exhibited a $96 \%$ stand compared with only $74 \%$ for the spring planting. Final yields after 4 years followed the same pattern, although only the soil $\mathrm{pH}$ effect was statistically significant (data not sown). At the time of these studies, ramps were almost exclusively wild-harvested, but the sale of cultivated ramps has increased dramatically since then.

Echinacea. Echinacea purpurea, also known as purple coneflower, is a popular ornamental and a widely used medicinal herb that many farmers want to grow. Echinacea's main use is to prevent infection from colds or flu or to lessen the symptoms and duration of them after infection. Although echinacea is an easy plant to grow, there is tremendous variability from crop to crop and farm to farm. Questions from the industry include, what does this mean to buyers, how can we guarantee quality across the state, and can we manipulate the plants to produce better quality? We conducted a greenhouse study to determine if we can manipulate plant growth, chemical constituents, and bioactivity by changing growing conditions (Davis et al., 2010). Plants were grown in soilless media in a factorial experiment with three initial soil $\mathrm{pH}$ levels $(5.85,6.35$, and 7.0$)$ and three fertilizer rates $\left(50,100\right.$, and $200 \mathrm{mg} \cdot \mathrm{kg}^{-1}$ media $\left.\mathrm{N}\right)$ with nine replications. Plants were harvested at different growth stages and analyzed for chicoric acid, caftaric acid, and the major alkylamide dodeca2E,4E,8Z,10E-tetraenoic acid isobutylamide. Plants responded to increasing $\mathrm{N}$ with more vigorous growth, greater numbers of blooms, and higher total biomass (data not shown). Soil $\mathrm{pH}$, however, had no effect (data not shown). Neither factor affected concentrations of the chemical constituents (data not shown). The practical application of these results is that growers of Echinacea purpurea can increase root and shoot yields by applying $\mathrm{N}$ without compromising concentrations of the chemical constituents that have been identified as being bioactively important.

\section{ISSUES WITH FARMERS GROWING MEDICINAL HERBS}

The Medicinal Herbs for Commerce Project and the supporting research have helped herb farmers, but more work is needed. Medicinal herbs can be profitable crops, but few North Carolina farmers grow them because they are unfamiliar with them. When farmers grow conventional crops, they usually have some familiarity with the plants and understand what a good-quality crop should look like. If they need more information or run into problems, they know there is a knowledgeable support network with Cooperative Extension, the land-grant universities, and the state department of agriculture to assist them. Medicinal herbs, however, are a big unknown. Farmers do not have experience growing herbs, they do not know what a quality crop is supposed to look like, they are uncertain about what buyers want, and they know that their support network does not have enough experience with these crops to help them with all the problems and questions that might arise. Growers, buyers, medicinal herb product manufacturers, and industry consultants have indicated in meetings and surveys that to grow this industry, more support is needed in terms of research and extension. They said that in addition to research on production, more needs to be done with processing, food safety, product efficacy, and clinical trials. Research into these latter two issues was requested to improve and stabilize market demand. Farmers and small manufacturers also requested better access to small business loans, business incubators, and shared-use processing facilities. The product manufacturers also said that consumers need to be better educated about how to judge the quality of products and safety of use.

\section{SUGGESTION TO FELLOW RESEARCHERS}

I propose that the scientific and academic communities could more effectively help this industry if they worked together. There are hundreds of medicinal herbs in commerce and it is impossible for a small number of independent research and extension programs to answer all the questions. I suggest that we create a consortium of researchers, extension specialists, and industry representatives to work together to assist this growing industry. By taking a systematic approach to addressing the biggest issues, we could quickly create a database of information for farmers and agricultural advisors trying to produce crops for this industry.

\section{Literature Cited}

American Herbal Products Association. 2006. Good agricultural and collection practice for herbal raw materials. 1 Feb. 2012. <http:// www.ahpa.org/Portals/0/pdfs/06_1208_AHPAAHP_GACP.pdf>.

Beyfuss, R.L. 2000. Soil nutrient characteristics of wild ginseng populations in New York, New Jersey, Maine and Tennessee, p. 105-114. In: Beyfuss, R.L. (ed.). Proc. Amer. Ginseng Production in the $21^{\text {st }}$ Century. Cornell Coop. Ext. of Greene County, Cairo, NY.

Davis, J.M., D. Reardon, A. Hamilton, V. Kandhi, A. Jarmusch, and N. Cech. 2010. Influence of nitrogen and $\mathrm{pH}$ on constituent levels and plant growth of greenhouse-grown Echinacea purpurea. HortScience 45(suppl):S217.

Konsler, T.R. and J.E. Shelton. 1990. Lime and phosphorus effects on American ginseng: I. Growth, soil fertility, and root tissue nutrient status response. J. Amer. Soc. Hort. Sci. 115: 570-574.

McCoy, J., J. Davis, N. Camper, I. Kahn, and A. Bharathi. 2007. Influence of rhizome propagule size on yields and triterpene glycoside concentrations of Actaea racemosa. HortScience 42:61-64.

McCoy, J.H. 2004. Development of seed and rhizome propagation protocols for Actaea racemosa L. (black cohosh) and analysis of associated triterpene glycosides. Ph.D. diss., Dept. of Plant Physiol., Clemson Univ., Clemson, $\mathrm{SC}$

Journal, N.B. 2011. A tough recipe for 6\% growth. Nutrition Business Journal 16(11/12):1-9.

Onofrietti, M. 2007. Propagation and cultivation of bloodroot (Sanguinaria canadensis). M.S. thesis, Depts. of Hort. Sci. and Crop Sci., North Carolina State Univ., Raleigh, NC. 1 Feb. 2012. $<$ http://repository.lib.ncsu.edu/ir/bitstream/1840. 16/2801/1/etd.pdf>.

Persons, W.S. and J.M. Davis. 2007. Growing and marketing ginseng, goldenseal, and other woodland medicinals. $2^{\text {nd }}$ printing. Bright Mountain Books, Fairview, NC.

U.S. Food and Drug Administration. 2012. Current good manufacturing practices. 17 Jan. 2012 $<$ http://www.fda.gov/Food/DietarySupplements/ GuidanceComplianceRegulatoryInformation/ RegulationsLaws/ucm079496.htm>. 